\title{
ANALISIS PERBUATAN MELAWAN HUKUM DALAM AKTA PERJANJIAN PENGIKATAN JUAL BELI (PPJB) TANAH ANTARA KOKO PURNOMO SANTOSO DENGAN PT. INTAN PLAZA ADIKA (Studi Kasus: \\ Putusan Mahkamah Agung Nomor 17/K/Pdt/2016)
}

\author{
Haryati Widjaja \\ (Mahasiswa Program S1 Fakultas Hukum Universitas Tarumanagara) \\ (email: haryatiwijaya16@gmail.com)
}

\section{Hanafi Tanawijaya, S.H., M.H.}

(Corresponding Author)

(Dosen Tetap Fakultas Ilmu Hukum Universitas Tarumanagara, meraih Sarjana Hukum (SH) dari

Universitas Tarumanagara tahun 1990 dan meraih gelar Magister Ilmu Hukum (MH) pada tahun 1997)

(email: hanafitanawijaya@gmail.com)

\begin{abstract}
Contract or agreement is an act pursuant to which one or more individuals commit themselves to one another. Based on the system that chapter III civil code used, chapter III civil code used opened system it means that every people can make an agreement with everybody and about anythings but the contract or agreement must be appropriate with terms of agreement and agreement principles. There are two kinds of agreement, first nominaat agreement, nominaat agreement is an agreement that already have a regulted in law. The second is innominaat agreement, innominaat agreement is an agreement that not regulated in law. condition sale and purchase agreement is innominaat agreement. Condition sale and purchase agreement was appeared because of freedom of contract. Eventhough condition sale and purchase agreement was made because freedom of contract but it must be appropriate with terms of agreement and agreement principles. If the agreement put aside the agreement principles and legal principles, the agreement can be null and void or can be canceled. In Koko Purnomo Santoso's case, he already been punished for 4 years because, Koko sold lands that belongs to someone else and gave the wrong information in authentic deed. But, Intan Plaza Adika still want to continue the agreement because Intan Plaza Adika is a purchaser with good faith. The district court and high court agree with Intan Plaza Adika. But the supreme court said the opposite with district and high court, the supreme court said the agreement is null and void.
\end{abstract}

Keywords: contract, sale, purchase, agreement. 


\section{PENDAHULUAN}

\section{A. Latar Belakang}

Manusia merupakan makhluk sosial (homo homini lupus) dimana dalam melakukan setiap aktivitasnya manusia senantiasa berinteraksi dengan satu sama lain. Interaksi yang dilakukan antar manusia melahirkan suatu hubungan yang dinamakan dengan hubungan hukum. Interaksi tersebut dapat berupa interaksi di bidang politik, sosial, budaya dan ekonomi seperti jual beli, sewa menyewa serta berbagai kegiatan ekonomi lainnya. Seiring dengan berkembangnya zaman, maka manusia memerlukan suatu kepastian hukum sebagaimana yang tertuang dalam Pasal 28D ayat 1 Undang-undang Dasar Negara Republik Indonesia Tahun 1945 (selanjutnya disebut dengan UUD NRI 1945) yang berbunyi "Setiap orang berhak atas pengakuan, jaminan, perlindungan, dan kepastian hukum yang adil serta perlakuan yang sama di hadapan hukum." Sehingga, dalam rangka mengimplementasikan Pasal 28D ayat 1 UUD NRI 1945 dalam kehidupan, maka diperlukan suatu wadah hukum, wadah hukum yang dimaksud ialah perjanjian atau kontrak yang mengatur tentang hak dan kewajiban para pihak dalam berinteraksi khususnya dalam bidang perekonomian yakni jual beli.

Kontrak atau perjanjian merupakan suatu peristiwa di mana seseorang berjanji kepada orang lain, atau di mana dua orang saling berjanji untuk melaksanakan sesuatu hal. ${ }^{1}$ Menurut Yahya Harahap perjanjian mengandung pengertian suatu hubungan hukum kekayaan atau harta benda antara dua orang atau lebih yang memberi kekuatan hak pada satu pihak untuk memperoleh prestasi sekaligus mewajibkan pada pihak lain untuk menunaikan prestasi. $^{2}$ Perjanjian diatur dalam buku III Kitab Undangundang Hukum Perdata (selanjutnya disebut dengan KUHPer), buku III

\footnotetext{
${ }^{1}$ R.Subekti, Pokok-Pokok Hukum Perdata, (Jakarta: Intermasa, 2001), hal. 36.

${ }^{2}$ M. Yahya Harahap, Segi-Segi Hukum Perjanjian, (Bandung: Alumni,1986), hal. 6.
} 
KUHPer menggunakan sistem terbuka sehingga setiap orang bebas untuk membuat perjanjian dengan siapa saja dan membuat perjanjian tentang apa saja, namun dalam membuat perjanjian perlu diperhatikan syarat-syarat sahnya perjanjian yang tertuang dalam Pasal 1320 KUHPer, yaitu: 1.) Kesepakatan; 2.) Kecakapan; 3.) obyek tertentu; dan 4.) Kausa yang halal. Syarat pertama dan kedua disebut sebagai syarat subjektif, sedangkan syarat ketiga dan keempat disebut sebagai syarat objektif. Perjanjian dibedakan menjadi 2 (dua) macam berdasarkan namanya, yaitu perjanjian bernama (nominaat) dan perjanjian tidak bernama (innominat). Perjanjian bernama merupakan perjanjian yang diatur atau dikenal dalam KUHPer, seperti perjanjian jual beli, sewa-menyewa, tukar-menukar, hibah, penitipan barang, pinjam pakai, dan sebagainya sedangkan, perjanjian tidak bernama (innominat) merupakan perjanjian yang belum ada pengaturannya dalam KUHPer.

Perjanjian tidak bernama (innominat) lahir dikarenakan adanya asas kebebasan berkontrak sebagaimana yang tertang dalam Pasal 1338 Ayat (1) KUHPer yang berbunyi demikian "Semua perjanjian yang dibuat secara sah berlaku sebagai undang-undang bagi mereka yang membuatnya." Perjanjian tidak bernama (innominat) diatur dalam Pasal 1319 KUHPer yang berbunyi "semua perjanjian, baik yang mempunyai nama khusus maupun yang tidak dikenal dengan suatu nama tertentu, tunduk pada peraturan umum yang termuat dalam bab ini dan bab yang lain.” Salah satu contoh dari perjanjian tidak bernama (innominat) adalah perjanjian pengikatan jual beli (selanjutnya disebut dengan PPJB).

Istilah PPJB memang tidak terdapat dalam undang-undang, namun banyak kita jumpai dalam kehidupan sehari-hari terutama timbul dalam praktek Notaris. PPJB merupakan perjanjian bantuan yang berfungsi 
sebagai perjanjian pendahuluan yang bentuknya bebas. ${ }^{3}$ PPJB tanah lahir sebagai akibat terhambatnya atau terdapat persyaratan yang diatur dalam undang-undang yang berkaitan dengan jual beli tanah dan akhirnya menghambat penyelesaian transaksi jual beli tanah. Persyaratan tersebut ada yang lahir dari undang-undang ataupun dari kesepakatan para pihak. Persyaratan yang lahir dari undang-undang misalnya jual beli harus sudah lunas terlebih dahulu baru Akta Jual Beli (selanjutnya disebut dengan AJB) dapat ditandatangani, sedangkan persyaratan yang lahir dari kesepakatan para pihak adalah persyaratan mengenai balik nama atas tanah yang diperjualbelikan atau belum dapat melakukan pelunasan seluruhnya terhadap harga yang telah disepakati.

Dalam membuat PPJB tentunya haruslah memperhatikan mengenai syarat-syarat sahnya perjanjian sebagaimana yang telah disebutkan diatas. Namun, dalam prakteknya isi dari perjanjian yang diperjanjikan tidak selamanya dapat berjalan sesuai dengan ketentuan yang berlaku. Dalam kondisi-kondisi tertentu dapat ditemukan terjadinya berbagai hal, yang berakibat terjadinya Perbuatan Melawan Hukum (selanjutnya disebut dengan PMH). Suatu objek dalam perjanjian dapat dikatakan mengandung unsur PMH apabila:

1.) Perbuatan yang dibuat bertentangan dengan hak orang lain;

2.) Perbuatan yang dibuat bertentangan dengan kewajibannya sendiri;

3.) Perbuatan yang dibuat bertentangan dengan kesusilaan;

4.) Perbuatan yang dibuat bertentangan dengan kehati-hatian atau keharusan dalam pergaulan masyarakat yang baik. ${ }^{4}$

Salah satu objek perjanjian yang diduga mengandung unsur PMH yaitu PPJB yang dibuat antara Koko Purnomo Santoso alias Koko dengan

\footnotetext{
${ }^{3}$ Herlien Budiono, Ajaran Umum Hukum Perjanjian Dan Penerapannya Di Bidang Kenotariatan, (Bandung: Citra Aditya Bakti,2014), hal. 98.

${ }^{4}$ Munir Fuady, Perbuatan Melawan Hukum Pendekatan Kontemporer, (Bandung:Citra Aditya Bakti, 2013), hal. 6.
} 
PT. Intan Plaza Adika dimana objek yang diperjanjikan masih terdaftar atas nama Ali santoso (almarhum). Kasus ini bermula pada saat Ali santoso (almarhum) yang merupakan orang tua kandung dari Koko mengatasnamakan 7(tujuh) bidang tanah tersebut kepada Koko dan 5(lima) orang karyawannya untuk menghindari pembayaran pajak yang besar karena, pada saat itu terdapat Surat Keputusan Gubernur Undang-undang No. 56 Prp Tahun 1960 tentang penetapan Luas Tanah Pertanian (selanjutnya disebut dengan UU Landreform) yang kemudian diatur secara lebih lanjut dalam Pasal 7 jo Pasal 17 UUPA yang mengatakan bahwa kepemilikan tanah tidak boleh melebihi dari 5 bidang. Adapun tanah yang diatasnamakan atas nama Koko dan 4(empat) orang karyawannya yaitu:

1. Girik Nomor C.1561 Persil 457 atas nama ke Betty Widya Handayani, luas tanah $1.618 \mathrm{M}^{2}$;

2. Girik Nomor C.1563 Persil 448 atas nama Koko Purnomo Santoso, luas tanah $1.685 \mathrm{M}^{2}$;

3. Girik Nomor C.1563 Persil 527 atas nama Betty Widya Handayani, luas tanah $3.045 \mathrm{M}^{2}$;

4. Girik Nomor C.1564 Persil 449 atas nama Wahyuni, BA., luas tanah $3.358 \mathrm{M}^{2}$;

5. Girik Nomor C.1570 Persil 457 atas nama Betty Widya Handayani, luas tanah 2.967 M2;

6. Girik Nomor C.1571 Persil 448 atas nama Koko Purnomo Santoso, luas tanah $2.000 \mathrm{M}^{2}$;

7. Girik Nomor C.356 Persil 137 atas nama Suhandi, luas tanah 3.903 M2;

Pada tanggal 14 Juni 1995 atas perintah Alie Santoso (almarhum) selaku pemilik tanah, Ahmad Latif menyerahkan sebanyak 7(tujuh) girik ke Badan Pertanahan Nasional Jakarta Timur (selanjutnya disebut dengan 
BPN Jakarta Timur) dalam rangka permohonan penyertifikatan atas tanahtanah tersebut dan dalam rangka kerjasama dengan PT. Summarecon Agung. Setelah 7(tujuh) girik tersebut diserahkam ke BPN Jakarta Timur, BPN Jakarta Timur menyerahkan tanda terima tersebut kepada Ahmad Latif dan Ahmad Latief memberikan tanda terima tersebut kepada Betty Widya Handayani sebagai Sekretaris PT. Surya Dewata dan tanda terima tersebut disimpan oleh Alie Santoso (almarhum) sebagai Direktur Utama PT. Surya Dewata, bahwa tanda terima dari BPN Jakarta Timur sampai saat ini ada pada dan disimpan oleh Alie Santoso (almarhum).

Kemudian PT. Summarecon Agung membatalkan kerja sama dengan PT. Surya Dewata. Karena mengetahui hal tersebut Koko memiliki niat buruk untuk mengambil 7(tujuh) girik tersebut dari BPN Jakarta Timur dan kemudian menjualnya untuk keuntungan diri sendiri dengan cara membuat surat keterangan hilang terhadap tanda bukti sertifikasi tanah di kantor kepolisian Jakarta Barat yang kemudian surat keterangan hilang tersebut diserahkan kepada BPN Jakarta Timur untuk mengambil girik-girik tersebut. Setelah berhasil mengambil girik tersebut dari BPN Jakarta Timur, Koko membuat kesepakatan dengan para karyawan Alie Santoso untuk memberikan kuasa kepadanya untuk menjual tanah-tanah tersebut. Setelah membuat kuasa kepada Koko untuk menjual tanah tersebut, Koko melakukan transaksi jual beli dengan PT. Intan Plaza Adika dengan dibuatkannya PPJB. Setelah proses PPJB dilakukan, Koko telah menerima uang hasil penjualan tanah seluas $18.576 \mathrm{M}^{2}$ dengan harga Rp.420.000,(empat ratus dua puluh ribu rupiah) per meter persegi, jumlah uang seluruhnya yang Terdakwa terima yakni sebesar Rp.7.800.000.000,- (tujuh milyar delapan ratus juta rupiah) dengan cara ditransfer ke rekening Koko.

Setelah mengetahui perbuatan Koko, Ali santoso (almarhum) segera menulis surat yang ditujukan untuk Lurah Duren Sawit yakni Yogi Metro 
Peni yang pada pokoknya menyatakan bahwa 7 (tujuh) bidang tanah tersebut masih merupakan miliknya dan meminta Yogi Metro Peni agar tidak melakukan peralihan girik atas tanah-tanah tersebut. Kemudian Ali santoso (almarhum) segera melaporkan perbuatan Koko kepada pihak Kepolisian agar segera diproses dan akhirnya Koko pun dijatuhi hukuman pidana kurang lebih 4 (empat) tahun yang dituangkan dalam putusan Nomor 767/K/Pid/2008.

Berdasarkan uraian latar belakang dan uraian kasus yang terdapat dalam latar belakang, maka penulis merasa tertarik untuk menganalisa lebih lanjut mengenai akibat hukum dari PPJB yang mengandung unsur PMH dan menyusunnya ke dalam sebuah skripsi yang berjudul “ANALISIS PERBUATAN MELAWAN HUKUM DALAM AKTA PERJANJIAN PENGIKATAN JUAL BELI (PPJB) TANAH ANTARA KOKO PURNOMO SANTOSO DENGAN PT. INTAN PLAZA ADIKA (Studi Kasus: Putusan Mahkamah Agung Nomor 17/K/Pdt/2016).”

\section{B. Permasalahan}

Berdasarkan latar belakang yang telah penulis uraikan diatas, maka penulis mengambil rumusan masalah tentang "Bagaimana akibat hukum dari Perjanjian Pengikatan Jual Beli (PPJB) yang mengandung unsur perbuatan melawan hukum dalam Putusan Mahkamah Agung Nomor 17/K/Pdt/2016?"

\section{PEMBAHASAN}

Perjanjian dalam hukum perjanjian merupakan kesepadanan dari istilah "overeenkomst" dalam Bahasa Belanda atau "agreement" dalam Bahasa Ingris. ${ }^{5}$ Pasal 1313 KUHPer memberikan definisi mengenai perjanjian yang berbunyi demikian:

\footnotetext{
${ }^{5}$ Munir Fuady, Hukum Kontrak, (Bandung: Citra Aditya Bakti, 2001), hal.2.
} 
perjanjian merupakan suatu perbuatan dimana satu orang atau lebih mengikatkan diri terhadap satu orang atau lebih.

Suatu perjanjian yang di buat oleh para pihak harus berdasarkan pada asas - asas perjanjian, hal ini penting untuk diperhatikan dalam pelaksanaan perjanjian karena asas perjanjian dijadikan sebagai pedoman, patokan, dan juga pegangan dalam melaksanakan perjanjian yang dibuat oleh para pihak. Adapun asas-asas yang harus diperhatikan oleh para pihak dalam membuat perjanjian adalah sebagai berikut:

a. Asas Konsensualisme

Perjanjian terbentuk karena adanya perjumpaan kehendak (consensus) dari para pihak, dengan demikian hukum perjanjian dalam buku III menganut asas konsensualisme. Konsensualisme memiliki makna bahwa perjanjian tersebut sudah mengikat bagi para pihak yang membuatnya sejak tercapainya kata sepakat. ${ }^{6}$ Sehingga suatu perjanjian tidak memerlukan formalitas tertentu atau perbuatan tertentu.

b. Asas Itikad Baik

Hukum perjanjian juga menganut asas itikad baik sebagaimana yang diatur dalam Pasal 1338 ayat (3) KUHPer yang berbunyi demikian "Persetujuan harus dilaksanakan dengan itikad baik." Asas itikad baik dalam perjanjian sangatlah penting agar perjanjian yang telah dibuat tidak bersifat merugikan salah satu pihak saja.

c. Asas Kepribadian

Asas kepribadian termuat dalam rumusan Pasal 1315 KUHPer, yang berbunyi demikian:

Pada umumnya seseorang tidak dapat mengadakan pengikatan atau perjanjian selain untuk dirinya sendiri.

\footnotetext{
${ }^{6}$ Akhmad Budi Cahyono dan Surini Ahlan Sjarif, Mengenal Hukum Perdata, (Jakarta: Gitama Jaya, 2008), hal. 133.
} 
Berdasarkan asas ini perjanjian hanya mengikat para pihak yang membuat perjanjian saja dan tidak mengikat bagi pihak ketiga namun, terhadap asas kepribadian ini terdapat pengecualian yang diatur dalam Pasal 1317 KUHPer yang berbunyi demikian:

Dapat pula diadakan perjanjian untuk kepentingan orang ketiga, bila suatu perjanjian yang dibuat untuk diri sendiri, atau suatu pemberian kepada orang lain, mengandung syarat semacam itu. Siapa pun yang telah menentukan suatu syarat, tidak boleh menariknya kembali, jika pihak ketiga telah menyatakan akan mempergunakan syarat itu.

Maksud dari ketentuan Pasal 1317 KUHPer ialah pihak ketiga dapat masuk ke dalam perjanjian yang di buat oleh para pihak apabila dalam hal yang diperjanjikan termuat hak-hak pihak ketiga. Dalam setiap perjanjian juga harus memperhatkan mengenai syarat sahnya perjanjian yang diatur dalam Pasal 1320 KUHPer yaitu: 1) kesepakatan; 2) kecakapan; 3) hal tertentu; dan 4) sebab yang halal. Selain itu terdapat hal yang harus diperhatikan juga yakni mengenai unsur-unsur dalam perjanjian yang terdiri dari unsur naturalia, esensialia, dan aksidentalia.

a. Unsur esensialia dalam perjanjian mewakili ketentuan-ketentuan berupa prestasi-prestasi yang wajib dilaksanakan oleh salah satu atau lebih pihak, yang mencerminkan sifat dari perjanjian tersebut. Unsur esensialia ini pada umumnya dipergunakan dalam memberikan rumusan, definisi atau pengertian dari suatu perjanjian. ${ }^{7}$ Unsur esensialia merupakan unsur yang wajib ada dalam suatu perjanjian.

b. Unsur naturalia, unsur naturalia adalah unsur yang telah diatur dalam undang-undang. Sehingga apabila tidak diatur oleh para pihak, maka undang-undanglah yang mengaturnya. Jadi, unsur naturalia adalah unsur yang selalu dianggap ada dalam perjanjian. ${ }^{8}$

\footnotetext{
${ }^{7}$ Kartini Muljadi dan Gunawan Widjaja, Perikatan Yang Lahir Dari Perjanjian, (Jakarta: RajaGrafindo Persada, 2010), hal. 85.

${ }^{8}$ R.Soeroso, Perjanjian Di Bawah Tangan, (Jakarta: Sinar Grafika, 2011), hal. 17.
} 
c. Unsur aksidentalia, unsur aksidentalia adalah unsur yang nanti ada atau mengikat para pihak jika para pihak memperjanjikannya. Dengan demikian unsur aksidentalia merupakan unsur pelengkap yang dapat dibuat secara menyimpang oleh para pihak sesuai dengan kehendak para pihak. $^{9}$

Setiap perjanjian yang dibuat haruslah memperhatikan mengenai hal-hal yang disebutkan di atas, agar perjanjian tersebut menjadi perjanjian yang baik dan benar.

Mengenai definisi jual beli tanah, Undang-undang Nomor 5 Tahun 1960 tentang Peratoran Dasar Pokok-pokok Agraria (selanjutnya disebut dengan UUPA) tidak menjelaskan secara khusus mengenai jual beli, akan tetapi dalam UUPA hanya disebutkan tentang peralihan hak atas tanah dimana salah satu bentuk peralihan hak atas tanah ialah melalui jual beli yang kemudian perallihak hak atas tanah tersebut diatur secara lebih lanjut dalam Peraturan Pemerintah Nomor 24 Tahun 1997 tentang Pendaftaran Tanah (yang selanjutnya disebut dengan PP No. 24/97). Jual beli tanah menurut UUPA tidak dituliskan secara jelas, akan tetapi dalam Pasal 5 UUPA dinyatakan bahwa:

Hukum agraria yang berlaku atas bumi, air dan ruang angkasa ialah hukum adat, sepanjang tidak bertentangan dengan kepentingan nasional dan Negara, yang berdasarkan atas persatuan bangsa, dengan sosialisme Indonesia serta dengan peraturan-peraturan yang tercantum dalam Undangundang ini dan dengan peraturan perundang-undangan lainnya, segala sesuatau dengan mengindahkan unsur-unsur yang bersandar pada hukum agama.

Sehingga pengertian jual beli dalam UUPA sama dengan pengertian jual beli dalam hukum adat. Jual beli tanah dalam hukum adat dilakukan secara terang dan tunai. Terang berarti, perbuatan pemindahan hak harus dilakukan dihadapan kepala adat yang berperan sebagai pejabat yang

\footnotetext{
${ }^{9}$ Kartini Muljadi dan Gunawan Widjaja, Op.cit., hal. 89.
} 
menanggung keteraturan dan sahnya perbuatan pemindahan hak tersebut, sehingga pemindahan hak tersebut diketahui oleh umum. Sedangkan tunai memiliki pengertian bahwa perbuatan pemindahan hak tersebut dilakukan pembayaran secara kontan atau dibayar sebagian untuk menjamin adanya perlindungan hukum dalam melaksnakan jual beli. ${ }^{10}$ Dalam hukum adat jual beli tanah bukanlah perbuatan hukum yang merupakan perjanjian obligatoir melainkan perbuatan hukum yang merupakan penyerahan hak atas tanah yang bersangkutan oleh penjual kepada pembeli untuk selama-lamanya pada pihak pembeli, kemudian pihak pembeli melunasi harga kepada penjual. Dengan dilaksanakannya jual beli tanah, hak milik atas tanah beralih kepada pembeli. Harga tanah yang dibayarkan itu bisa seluruhnya, tetapi dapat juga sebagian. Tetapi biarpun baru dibayar sebagian, menurut hukum dianggap telah dibayar penuh. Objek yang diperjualbelikan dalam transaksi jual beli dapat berupa tanah-tanah hak:

a. Hak Milik

Hak milik (selnjutnya disebut dengan HM) merupakan hak turuntemurun terkuat dan terpenuh yang dapat dipunyai oleh orang atas tanah dengan mengingat fungsi sosial yang di atur dalam ketentuan Pasal 6 UUPA. ${ }^{11}$ Turun-temurun berarti dapat dikuasai tanahnya secara terusmenerus dan akan beralih karena hukum kepada ahli warisnya sedangkan, terpenuh artinya penguasaan tanahnya tidak terputus-putus dan kewenangan pemilik untuk diusahakan maupun untuk keperluan membangun sesuatu selama peruntukan tanahnya belum dibatasi oleh ruang tata kota dan ruang wilayah. HM hanya dapat diberikan kepada orang yang berkewarganegaraan Indonesia dan badan-badan hukum yang sudah ditentukan.

${ }^{10}$ Budi Harsono, Hukum Agraria Indonesia, Sejarah Pembentukan Undang-undang Pokok Agrarian, Isi Dan Pelaksanaannya, (Jakarta: Djambatan, 1997), hal. 51.

${ }^{11}$ Ibid., hal.295. 
b. Hak Guna Bangunan

Hak guna bangunan (selanjutnya disebut dengan HGB) memberikan wewenang untuk mendirikan bangunan di atas tanah kepunyaan pihak lain. Jangka waktu yang diberikan yakni 30 (tiga puluh) tahun. Dan dapat diperpanjang jangka waktunya 20 (dua puluh) tahun dan jika masih diperlukan dapat diperbaharui hak tersebut. Untuk perusahaan dalam rangka penanaman modal dapat diberikan sekaligus 80 (delapan puluh) tahun. HGB hanya dapat diberikan kepada Warga Negara Indonesia dan badan hukum Indonesia. ${ }^{12}$

c. Hak Guna Usaha

Hak guna usaha (selanjutnya disebut dengan HGU) memberikan wewenang untuk menggunakan tanahnya yang langsung dikuasai negara untuk usaha seperti pertanian, perkebunan, perikanan, peternakan selama jangka waktu tertentu, yaitu 25 (dua puluh lima) dan 35 (tiga puluh lima) tahun dan dapat diperpanjang jangka waktunya 25 (dua puluh lima) tahun dan apabila masih diperlukan, maka dapat diperbaharui haknya, yaitu diberikan kembali 35 (tiga puluh lima) tahun. Sedangkan untuk perusahaan yang bergerak dalam bidang usaha penanaman modal diberikan sekaligus 95 (Sembilan puluh lima) tahun. Hgu dapat diberikan kepada Warga Negara Indonesia dan badan hukum Indonesia. ${ }^{13}$

d. Hak Pakai

Hak pakai memberikan wewenang untuk menggunakan tanah kepunyaan pihak lain selama jangka waktu tertentu yaitu 25 (dua puluh lima) tahun dan dapat diperpanjang selama 20 (dua puluh) tahun dan jika masih diperlukan dapat diperbaharui hak tersebut. Untuk perusahaan dalam rangka penanaman modal dapat diberikan sekaligus 75 (tujuh puluh) tahun. Hak pakai dapat diberikan kepada Warga Negara

\footnotetext{
${ }^{12}$ Ibid.

${ }^{13}$ Ibid.
} 
Indonesia, badan hukum Indonesia, orang asing yang berkedudukan di Indonesia, badan hukum asing yang mempunyai kantor perwakilan di Indonesia, Departemen, Lembaga Non Departemen Dan Pemerintahan Daerah, badan keagamaan dan social, serta perwakilan negara asing dan perwakilan badan internasional. ${ }^{14}$

e. Tanah tanpa atau berikut bangunan yang berdiri di atasnya

Dalam hal banguna ikut menjadi objek jual beli, maka terdapat persyaratan, antara lain:

1) Bahwa bangunan/ benda tersebut menurut sifatnya menjadi satu kesatuan dengan tanah;

2) Bahwa pemegang hak atas tanah yang bersangkutan adalah pemilik bengunan/benda tersebut;

3) Dalam akta jual beli harus dinyatakan secara tegas bahwa objek jual belinya meliputi tanah hak yang bersangkutan. ${ }^{15}$

Hal tersebut dikarenakan sistem hukum pertanahan kita menganut asas pemisahan horizontal sehingga antara tanah dengan bangunan serta tanaman yang berdiri diatasnya bukanlah satu kesatuan. Sehingga, apabila dalam jual beli tanah dimana diatas tanah tersebut terdapat bangunan haruslah dinyatakan secara jelas dalam akta jual beli apakah bangunan tersebut termasuk ke dalam objek yang diperjualbelikan atau tidak.

f. Hak Milik atas Satuan Rumah Susun.

Hak Milik atas Satuan Rumah Susun (selanjutnya disebut dengan HM-SRS) adalah hak untuk memiliki satuan rumah susun secara terpisah dan berdiri sendiri berikut hak atas bagian bersama, benda bersama, dan

\footnotetext{
${ }^{14}$ Ibid.

${ }^{15}$ Ibid., hal.266.
} 
tanah bersama yang merupakan satu kesatuan yang tidak terpisahkan dengan satuan yang bersangkutan. ${ }^{16}$

Dalam hal pembayaran baru sebagian, maka biasanya para pihak membuat Perjanjian Pengikatan Jual Beli (yang selanjutnya disebut dengan PPJB). Pengertian dari PPJB adalah perjanjian bantuan yang berfungsi sebagai perjanjian pendahuluan yang bentuknya bebas. ${ }^{17}$ PPJB sebenarnya tidak ada perbedaan dengan perjanjian lainnya hanya saja PPJB lahir karena adanya asas kebebasan berkontrak yang diatur dalam Pasal 1338 ayat (1) KUHPer, yang memberikan kebebasan seluas-luasnya untuk membuat perjanjian tentang apa saja dan dengan siapa saja asalkan tidak melanggar kesusilaan, ketertiban umum, dan undang-undang. PPJB tanah memang tidak kita temui dalam UUPA maupun dalam KUHPer, namun dapat kita jumpai dalam praktek terutama timbul dalam praktek Notaris. PPJB. PPJB tanah dibuat karena belum terpenuhinya unsur-unsur dalam transaksi jual beli, seperti:

1. Pembayaran terhadap objek jual beli belum dapat dilunaskan;

2. Surat-surat atau dokumen tanah masih dalam proses/belum lengkap;

3. Obyek atau bidang tanah belum dapat dikuasai oleh para pihak, pihak penjual ataupun pihak pembeli, dalam hal ini pemilik asal ataupun pemilik baru;

4. Besaran obyek jual beli masih dalam pertimbangan para pihak.

Dalam studi kasus yang penulis pakai, PPJB yang dibuat antara Koko Purnomo Santoso dengan PT. Intan Plaza Adika merupakan perjanjian yang dibuat dalam bentuk akta otentik, akta otentik ialah suatu akta yang dibuat dalam bentuk yang ditentukan undang-undang oleh atau dihadapan pejabat umum yang berwenang untuk itu di tempat akta itu dibuat. Suatu PPJB

\footnotetext{
${ }^{16}$ Ibid., hal.352.

${ }^{17}$ Herlien Budiono, Ajaran Umum Hukum Perjanjian Dan Penerapannya Di Bidang Kenotariatan, (Bandung: Citra Aditya Bakti,2014), hal. 57.
} 
dikatakan sebagai PPJB yang baik apabila dalam PPJB tersebut dicantumkan jangka waktu berlakunya karena PPJB merupakan perjanjian yang sifatnya belum tuntas. Jangka waktu dalam PPJB dianggap penting karena agar menciptakan kepastian hukum bagi pembeli dan penjual mengenai kapan dokumen-dokumen bukti kepemilikkan atas tanah dapat diserahkan kepada pembeli dan kapan penjual dapat menerima pembayaran sejumlah uang pelunasan. Pendapat yang penulis sampaikan sesuai dengan hasil wawancara antara penulis dengan Bapak Benny Djaja sebagai pihak Notaris dan Bapak Hasni sebagai pihak akademisi. Bapak Benny Djaja mengatakan bahwa "PPJB merupakan perjanjian pendahuluan yang sifatnya sementara, jadi belum tuntas perbuatan hukumnya. Setelah janji-janji dalam PPJB terpenuhi, PPAT akan membuatkan AJB, apabila AJB sudah jadi dan sudah ditandatangani, maka perbuatan hukumnya sudah selesai dan haknya juga sudah beralih." Akan tetapi, penulis kurang sependapat mengenai hak atas tanahnya sudah beralih. Menurut penulis, hak atas tanah baru beralih ketika dilakukan pendaftaran hak atas tanah, karena hukum pertanahan nasional kita menganut sistem publikasi, dan sistem publikasi yang dianut oleh hukum pertanahan nasional kita adalah sistem publikasi negatif yang memuat unsur positif, maksudnya adalah perbuatan pemindahan hak baru beralih ketika dilakukan pendaftaran dan dimuat dalam buku tanah. Dengan demikian, penjual sudah tidak lagi menjadi pemegang hak atas tanah tersebut dan apa yang tercatat dalam buku tanah dianggap benar sampai ada yang membuktikan sebaliknya. Selanjutnya, Bapak Hasni mengatakan bahwa "PPJB merupakan pejanjian pada umumnya dengan memuat syarat batal sehingga apabila janji-janji dalam PPJB tidak terpenuhi pada waktu yang ditentukan, perjanjian tersebut batal dan pencantuman jangka waktu itu harus ada agar mengandung suatu kepastian."

PPJB yang dibuat oleh Koko Purnomo Santoso dengan PT. Intan Plaza Adika tidaklah mempunyai kekuatan hukum yang tetap karena PPJB yang 
dibuat bertentangan dengan syarat sahnya perjanjian dan juga bertentangan dengan hak orang lain serta undang-undang. Penulis dapat mengatakan demikian, karena tanah yang dijual oleh Koko Purnomo Santoso merupakan tanah milik Alie Santoso dan Koko menjual tanah tersebut tanpa sepengetahuan dan ijin dari Alie Santoso. Karena perbuatan Koko Purnomo Santoso yang demikian, Koko dilaporkan oleh ayahnya dan dijatuhi hukuman pidana penjara selama 4(empat) tahun yang dituangkan di dalam putusan pidana Nomor 2061/Pid.B/2007/ PN.Jkt.Tim jo putusan pidana Nomor 767 K/Pid/2008 yang telah berkekuatan hukum tetap karena telah secara sah dan meyakinkan menjual tanah milik orang lain dan menempatkan keterangan palsu ke dalam akta autentik. Dengan demikian, Koko Purnomo Santoso telah melakukan perbuatan melawan hukum (yang selanjutnya disebut dengan PMH) dan PPJB tersebut tidak didasari dengan causa yang halal.

Secara klasik atau lebih tepatnya sebelum tahun 1919 PMH diartikan sebagai:

a. tidak berbuat sesuatu yang diwajibkan oleh hukum;

b. perbuatan yang dilakukan secara salah, perbuatan mana merupakan kewajibannya atau merupakan perbuatan yang dia mempunyai hak untuk melakukannya; dan

c. perbuatan yang dilakukan padahal pelakunya tidak berhak untuk melakukannya.

Setelah tahun 1919 terdapat perluasan makna PMH. Suatu objek dalam perjanjian dapat dikatakan mengandung unsur PMH apabila objek tersebut diperoleh melalui:

5.) Perbuatan yang dibuat bertentangan dengan hak orang lain;

6.) Perbuatan yang dibuat bertentangan dengan kewajibannya sendiri;

7.) Perbuatan yang dibuat bertentangan dengan kesusilaan; 
8.) Perbuatan yang dibuat bertentangan dengan kehati-hatian atau keharusan dalam pergaulan masyarakat yang baik. ${ }^{18}$

Indonesia merupakan salah satu negara yang menganut aliran PMH dalam arti luas, hal tersebut dapat kita lihat dari hukuman pidana dan putusan perkara perdata yang dijatuhkan atas perbuatan Koko Purnomo Santoso. Majelis hakim tidak hanya memutus karena telah melanggar ketentuan yang terdapat dalam undang-undang saja, melainkan juga perbuatan yang bertentangan dengan hak orang lain, bertentangan dengan kewajibannya sendiri, bertentangan dengan kesusilaan, dan bertentangan dengan kehati-hatian atau keharusan dalam pergaulan masyarakat yang baik.

Mengenai akibat hukum dari perbuatan PMH yang dilakukan oleh Koko Purnomo Santoso selain mengajukan gugatan secara pidana, pihak keluarga juga dapat mengajukan gugatan secara perdata untuk meminta sejumlah uang ganti rugi. Konsep ganti rugi yang dikenal oleh hukum adalah sebagai berikut:

a. Ganti rugi nominal

Jika perbuatan melawan hukum mengandung unsur kesengajaan, tetapi tidak menimbulkan kerugian nyata bagi korban, maka kepada korban dapat diberikan sejumlah uang tertentu sesuai dengan rasa keadilan tanpa menghitung berapa sebenarnya jumlah kerugian tersebut. ${ }^{19}$

b. Ganti rugi Kompensasi

Ganti rugi kompensasi merupakan ganti rugi yang merupakan pembayaran kepada korban atas dan sebesar kerugian yang benar-benar telah dialami oleh pihak korban dari suatu perbuatan melawan hukum.

c. Ganti rugi penghukuman ${ }^{20}$

\footnotetext{
${ }^{18}$ Munir Fuady, Perbuatan Melawan Hukum Pendekatan Kontemporer, (Bandung:Citra Aditya Bakti, 2013), hal. 6.

${ }^{19}$ Munir fuady, Op.Cit., hal. 134.

${ }^{20}$ Ibid.
} 
Ganti rugi penghukuman merupakan suatu ganti rugi dalam jumlah besar yang melebihi dari jumlah kerugian yang sebenarnya. Besarnya jumlah ganti rugi tersebut dimaksudkan sebagai hukuman bagi si pelaku. ${ }^{21}$

Dengan adanya putusan pidana yang diberikan oleh Pengadilan Negeri Jakarta Timur, maka seharusnya PPJB tersebut batal demi hukum. Namun, dalam studi kasus yang saya gunakan pihak PT. Intan Plaza Adika tetap menuntut agar janji-janji yang tertuang dalam PPJB tetap dipenuhi dengan cara mengajukan gugatan perdata ke Pengadilan Negeri Jakarta Timur dan dengan alasan bahwa PT. Intan Plaza Adika merupakan pembeli dengan itikad baik. Kemudian Pengadilan Negeri Jakarta Timur memutus perkara tersebut melalui putusan nomor 117/Pdt.G/2014/PN.JKT.TIM. amar putusan tersebut menyatakan bahwa: 1) agar pihak lurah duren sawit segera mengeluarkan segala macam dokumen yang diperlukan untuk proses balik nama dan sertifikasi; 2) agar kantor Badap Pertanahan Nasional segera melakukan proses balik nama dan proses sertifikasi; 3). PPJB yang dibuat oleh Koko Purnomo Santoso dengan PT. Intan Plaza Adika sah, karena PT. Intan Plaza Adika merupakan pembeli dengan itikad baik. Putusan nomor 117/Pdt.G/2014/PN.JKT.TIM dikuatkan oleh Pengadilan Tinggi melalui putusan nomor 117/PDT/2015/PT DKI.

Berdasarkan Surat Edaran Mahkamah Agung Nomor 4 Tahun 2016 (yang selanjutnya disebut dengan SEMA No.4 Tahun 2016) salah satu syarat sebagai pembeli yang beritikad baik ialah melakukan penelitian terlebih dahulu mengenai status tanah objek jual beli dan berdasarkan hasil penelitiannya menunjukkan bahwa benar si penjual adalah pemilik asli dan pada saat sidangperkara pidana di gelar Direktur Utama PT. Intan Plaza Adika turut menghadiri sidang tersebut dan memberikan keterangannya sebagai saksi sehingga, PT. Intan Plaza Adika juga sudah menegtahui bahwa tanah

\section{${ }^{21}$ Ibid.}


tersebut bukanlah milik Koko Purnomo Santoso melainkan milik Alie Santoso dan dengan demikian alasan bahwa PT. Intan Plaza Adika sebagai pembeli yang beritikad baik tidak benar. Sehingga penulis berpendapat bahwa putusan yang tepat adalah putusan yang dituangkan dalam putusan nomor 17 $\mathrm{K} / \mathrm{Pdt} / 2016$ yang menyatakan sebagai berikut:

1. Akta Pengikatan Jual Beli atas objek sengketa antara para pihak telah terjadi kesepakatan yang didasarkan atas causa yang tidak halal, karena Tergugat I telah dijatuhi pidana dengan putusan yang berkekuatan hukum tetap (BHT) atas perbuatannya berkaitan dengan Mengabulkan permohonan kasasi dari Para Pemohon Kasasi: menjual tanah milik orang lain dan memberikan keterangan palsu pada akta otentik tersebut mengenai 7 (tujuh) bidang tanah objek sengketa, sehingga kesepakatan tersebut harus dinyatakan batal demi hukum;

2. Bahwa Judex Facti telah salah menerapkan perlindungan hukum kepada Penggugat/Termohon Kasasi atas dasar doktrin pembeli beriktikad baik, karena Penggugat/Termohon Kasasi dalam perkara a quo tidak memenuhi kualitas atau kriteria sebagai pembeli tanah beriktikad baik;

3. Bahwa menurut Surat Edaran Mahkamah Agung RI Nomor 5 Tahun 2014, tanggal 1 Desember 2014, pembelian tanah yang belum terdaftar dilakukan secara tunai dan terang. Pengertian terang adalah dilakukan di hadapan Kepala Desa setempat. Dalam perkara ini, pembeli tidak berusaha mencari informasi kepada Kepala Desa atau Kelurahan yang wilayahnya meliputi objek sengketa untuk memastikan siapa sesungguhnya pemilik tanah yang akan dibeli. Perjanjian jual beli tanah yang belum terdaftar tidak cukup hanya dengan dilakukan di hadapan PPAT tetapi harus memperoleh keterangan kepemilikan dari Lurah atau Kepala Desa setempat. Oleh karena pembeli dalam perkara a quo tidak berusaha mencari informasi dari Lurah atau Kepala Desa setempat, maka pembeli tidak dapat dikategorikan sebagai pembeli beriktikad baik. Oleh karenanya 
Penggugat/Termohon Kasasi tidak berhak memperoleh perlindungan hukum; Menimbang, bahwa berdasarkan pertimbangan di atas, menurut pendapat Mahkamah Agung terdapat cukup alasan untuk mengabulkan permohonan kasasi dari Para Pemohon Kasasi: KOKO PURNOMO SANTOSO ('KOKO’) dan kawan-kawan, tersebut dan membatalkan Putusan Pengadilan Tinggi Jakarta Nomor 117/PDT/2015/PT DKI tanggal 8 April 2015 yang menguatkan Putusan Pengadilan Negeri Jakarta Timur Nomor 117/Pdt.G/2014/PN Jkt.Tim., tanggal 28 Oktober 2014 serta Mahkamah Agung mengadili sendiri perkara ini dengan amar putusan sebagaimana yang akan disebutkan di bawah ini; Menimbang, bahwa oleh karena Termohon Kasasi/Penggugat berada di pihak yang kalah, maka harus dihukum untuk membayar biaya perkara dalam semua tingkat peradilan;

4. Menghukum Termohon Kasasi/Penggugat untuk membayar biaya perkara dalam semua tingkat peradilan yang dalam tingkat kasasi ini ditetapkan sejumlah Rp500.000,00 (lima ratus ribu rupiah);

Sebagai bentuk ganti rugi akibat perbuatan yang dilakukan oleh Koko Purnomo Santoso, dalam putusan nomor 17 K/Pdt/2016 Koko bersedia mengembalikan sejumlah uang yang telah diterimanya dari PT. Intan Plaza Adika.

Meskipun dalam studi kasus yang penulis pakai pihak Notaris tidak diikutsertakat sebagai pihak turut tergugat, berpendapat bahwa Notaris sebagai pihak yang membuat PPJB juga harus bertindak secara seksama sebagaimana yang diatur dalam Pasal 16 ayat (1) Undang-undang Nomor 30 Tahun 2004 jo Undang-undang Nomor 2 Tahun 2016 tentang Jabatan Notaris (yang selanjutnya disebut dengan UUJN), dan sebagai seorang Notaris tentu saja tidak hanya mementingkan kepentingan dirinya sendiri melainkan harus melindungi kepentingan kliennya sebagaimana yang tertuang dalam Pasal 16 ayat (1) sehingga seharusnya sebagai seorang Notaris juga harus melakukan 
pengecekkan secara menyeluruh terlebih dahulu agar kliennya tidak mendapatkan masalah dikemudian hari selain itu dalam Pasal 15 ayat (2) huruf d UUJN dikatakan bahwa Notaris memiliki kewenangan untuk melakukan penyuluhan hukum sehubungan dengan pembuatan akta jadi, sudah seharusnya sebagai seorang Notaris memberikan penjelas mengenai isi perjanjian yang dikehendaki oleh para pihak harus bagaimana dan seperti apa walaupun sifat dari perjanjian bebas seperti yang dikehendaki oleh para pihak, namun disini seharusnya Notaris sebagai orang yang mengerti hukum harus memberikan arahan dan penjelasan kepada para pihak mengenai bagaimana PPJB harusnya dibuat.

\section{PENUTUP}

\section{A. Kesimpulan}

Berdasarkan penelitian yang telah diuraikan pada bab sebelumnya, penulis menyimpulkan bahwa PPJB merupakan suatu perjanjian yang lahir karena adanya asas kebebasan berkontrak sebagaimana yang di atur dalam Pasal 1338 ayat (1) KUHPer, dengan demikian isi dan bentuknya diserahkan kepada para pihak. Meskipun, isi dan bentuknya dibuat secara bebas PPJB tetaplah merupakan perjanjian pada umumnya sehingga dalam pembuatannya juga harus memperhatikan mengenai syarat-syarat sahnya perjanjian dan prinsip-prinsip umum dalam membuat suatu perjanjian. Selain itu, PPJB merupakan perjanjian pendahuluan sebelum dibuatkannya AJB. Dengan demikian, PPJB merupakan perjanjian yang sifatnya perjanjian bersyarat. Oleh karena itu, dalam pembuatan PPJB terdapat jangka waktu yang ditentukan oleh para pihak untuk pemenuhan pelaksanaan janji-janji agar dapat ditindaklanjuti dengan dibuatkannya AJB. Dalam PPJB tanah yang dibuat antara Koko Purnomo Santoso dengan PT. Intan Plaza Adika, tanah yang dijadikan sebagai objek PPJB diperoleh oleh Koko dengan cara yang tidak halal, yakni dengan adanya unsur penipuan. Selanjutnya, perbuatan Koko Purnomo Santoso yang 
menjual tanah milik Alie Santoso tanpa mendapatkan izin terlebih dahulu dari Alie Santoso juga merupakan perbuatan melawan hukum terlebih lagi Koko Purnomo Santoso telah dijatuhi hukuman pidana penjara selama 4(empat tahun) karena terbukti secara sah dan meyakinkan telah menjual tanah milik orang lain dan menempatkan keterangan palsu ke dalam otentik. Dengan demikian PPJB tersebut seharusnya tidak dimintakan pemenuhan janji-janjinya dan seharusnya dimintakan pembatalan dengan syarat pengembalian sejumlah uang yang telah dibayarkan karena, apabila kita melihat syarat sahnya perjanjian dan prinsip-prinsip umum perjanjian, maka PPJB yang dibuat tidak memenuhi dua hal tersebut dimana PPJB yang dibuat tidak didasari dengan adanya itikad baik dari pembeli maupun penjual dan tidak memenuhi syarat sahnya perjanjian yang di atur dalam Pasal 1320 KUHPer mengenai suatu perjanjian harus dibuat dengan kausa yang halal. Sehingga, PPJB tersebut seharusnya dinyatakan batal demi hukum dan sebagai bentuk ganti kerugian yang dialami oleh PT. Intan Plaza Adika, Koko Purnomo Santoso dapat mengembalikan sejumlah uang yang telah diterimanya dari PT. Intan Plaza Adika. Sedangkan sebagai akibat hukum dari perbuatan melawan hukum yang dilakukan oleh Koko Purnomo Santoso terhadap Alie Santoso, Alie Santoso dapat mengajukan gugatan secara perdata untuk meminta sejumlah uang ganti rugi. Hal tersebut sesuai dengan sebagaimana yang telah di atur dalam Pasal 1365 KUHPer yang mengatakan bahwa "Tiap perbuatan yang melanggar hukum dan membawa kerugian kepada orang lain, mewajibkan orang yang menimbulkan kerugian itu karena kesalahannya untuk menggantikan kerugian tersebut" dengan demikian Alie Santoso dapat menuntut sejumlah uang ganti rugi kepada Koko Purnomo Santoso akibat perbuatan yang dilakukan oleh Koko.

\section{B. Saran}


Penulis memberikan beberapa saran yang sekiranya dapat dijadikan sebagai bahan pertimbangan dalam pembuatan PPJB. Adapun saran tersebut dapat memberikan pengetahuan serta sebagai bentuk perlindungan hukum bagi pihak yang membuat dan juga masyarakat yang akan membuat PPJB.

1. Bagi masyarakat umum, dalam hal pembuatan PPJB dimana objeknya berupa tanah yang masih berstatus tanah girik, maka sebagai pembeli yang beritikad baik haruslah menyelidiki secara lebih lanjut mengenai asal usul dan riwayat kepemilikan tanah di kantor kelurahan, pernyataan bebas sengketa dan apabila perlu dimintakan surat pernyataan yang menyatakan bahwa tanah girik tersebut adalah benar milik penjual. Selain itu, selaku pembeli juga seharusnya menanyakan juga kepada pihak keluarga asal usul perolehan tanah tersebut apakah benar bahwa tanah tersebut sudah benar-benar beralih kepememilikan hak atas tanahnya atau belum.

2. Bagi pemerintah, dalam pemberian surat girik yang telah didaftarkan untuk proses sertifikasi seharusnya kantor pertanahan setempat tidak boleh langsung percaya dengan surat keterangan hilang yang ditunjukkan oleh orang lain kepadanya melainkan harus melakukan verifikasi terlebih dahulu kepada orang yang menerima bukti daftar surat girik tersebut apakah benar bukti daftar yang diserahkan oleh kantor pertanahan setempat hilang atau tidak.

3. Bagi para pihak yang terkait dalam pembuatan PPJB dalam hal ini terutama Notaris sebagai seorang Notaris haruslah menjalankan tugasnya secara seksama sebagaimana yang diamantakan dalam Pasal 16 UUJN. Maksudnya adalah menjalankan tugas dan wewenangnya dengan prinsip kehati-hatian. Selain itu seorang notaris juga harus memberikan penyuluhan hukum guna menjaga kepentingan kliennya agar dikemudian hari tidak terjadi masalah sebagaimana yang diamanatkan 
dalam Pasal 15 ayat (2) huruf d UUJN. Sedangkan untuk PT. Intan Plaza Adika, sebagai calon pembeli seharusnya juga lebih teliti dalam menyelidiki mengenai asal usul kepemilikan tanah dan tidak meminta pemenuhan terhadap janji-janji PPJB apabila sudah mengetahui bahwa tanah yang dijadikan sebagai objek merupakan tanah milik orang lain. Sedangkan, dalam pembuatan PPJB sebagai seorang penjual seharusnya tidaklah melakukan pengikatan jual beli dengan adanya unsur penipuan karena hal tersebut dapat merugikan pihak pembeli dan juga dapat memberikan kerugian kepada dirinya sendiri.

\section{DAFTAR PUSTAKA}

\section{A. BUKU}

Ali, H. Zainuddin. Metode Penelitian Hukum. (Jakarta: Sinar Grafika, 2016)

Budiono, Herlien. Ajaran Umum Hukum Perjanjian Dan Penerapannya Di Bidang Kenotariatan. (Bandung: Citra Aditya Bakti,2014)

Cahyono, Akhmad Budi dan Surini Ahlan Sjarif. Mengenal Hukum Perdata. (Jakarta: Gitama Jaya, 2008)

Fuady, Munir. Hukum Kontrak. (Bandung: Citra Aditya Bakti, 2001)

Fajar, Mukti dan Yulianto Achmad. Dualisme Penelitian Hukum dan Empiri. Cetakan ke-1. (Yogyakarta: Pustaka Pelajar, 2010)

Fuady, Munir. Perbuatan Melawan Hukum Pendekatan Kontemporer. (Bandung:Citra Aditya Bakti, 2013)

Harsono, Budi. Hukum Agraria Indonesia, Sejarah Pembentukan Undangundang Pokok Agrarian, Isi Dan Pelaksanaannya. (Jakarta:

Djambatan, 1997)

Harahap, M. Yahya. Segi-Segi Hukum Perjanjian. (Bandung: Alumni,1986)

Irianto, Sulistyowati dan Shidarta. Metode Penelitian Hukum Konstelasi dan Refleksi. cetakan ke-2. (Jakarta: Yayasan Pustaka Obor, 2011)

Khairandy, Ridwan. Perjanjian Jual Beli. (Yogyakarta: FH UII Press, 2016)

Muhammad, Abdulkadir. Hukum Perjanjian. (Bandung: Alumni, 1986), Aditya Bakti, 2000), Hukum Perdata Indonesia. (Bandung: Citra

Moeljatno. Asas-Asas Hukum Pidana. (Jakarta: Rineka Cipta, 2008) 
Muljadi, Kartini dan Gunawan Widjaja. Perikatan Yang Lahir Dari Perjanjian. (Jakarta: Raja Grafindo Persada, 2010)

Marzuki, Peter Mahmud. Penelitian Hukum Edisi Revisi. (Jakarta: Prenamedia Group, 2014)

Patrik, Purwahid, dasar-dasar hukum perikatan. (Bandung: Mandar Maju, 1994),

Subekti, R, Pokok-Pokok Hukum Perdata. (Jakarta: Intermasa, 2001)

Subekti, R., Hukum Perjanjian. (Jakarta: Intermasa, 2004)

Soeroso, R., Perjanjian Di Bawah Tangan. (Jakarta: Sinar Grafika, 2011)

J.,Satrio. Wanprestasi Menurut KUHPer, Doktrin, Dan Yurisprudensi. (Bandung: Citra Aditya Bakti, 2014)

\section{B. PERATURAN PERUNDANG-UNDANGAN}

Undang-undang Dasar Negara Republik Indonesia 1945

Indonesia. Kitab Undang-undang Hukum Perdata

Indonesia. Undang-undang Nomor 5 Tahun 1960 tentang Peraturan Dasar Pokok-Pokok Agraria

Indonesia. Undang-undang Nomor 30 Tahun 2004 jo. Undang-undang Nomor 2 Tahun 2016 tentang Jabatan Notaris

Indonesia. Undang-undang No. 56 Prp Tahun 1960 tentang penetapan Luas Tanah Pertanian

Surat Edaran Mahkamah Agung Nomor 4 Tahun 2016 tentang Pembeli yang beritikad baik

C. JURNAL

Mulyono, Bambang Eko, Jurnal Independent: Pelaksanaan Peralihan Hak Atas Tanah Berdasarkan Perjanjian Pengikatan Jual Beli dan Kuasa untuk menjual yang dibuat oleh Notaris". Volume 2.

Supriyadi, Arena Hukum: Kedudukan Perjanjian Pengikatan Jual Beli Hak atas Tanah Dalam Perspektif Hukum Pertanahan, Volume 9, Nomor 2, Agustus 2016

D. ARTIKEL INTERNET

http://lbhamin.org/perbuatan-melawan-hukum/ di akses pada hari Sabtu, tanggal 31 Maret 2018 pukul 11.45 WIB.

Dadang Sukandar. Pahami Perbedaan Hukum dari PPJB dan AJB, (KOMPAS.com, 4

Mei 2013, pkl. 12.01WIB) 